\title{
Environmental management complexities and rumours impeding the effective application of scientific research and results to address possible health risks in the West Rand gold mining region of South Africa
}

\author{
E. S. van Eeden ${ }^{1}$, E. J. Nealer ${ }^{2} \&$ M. Liefferink ${ }^{3}$ \\ ${ }^{1}$ School for Basic Sciences, North-West University, South Africa \\ ${ }^{2}$ School for Social and Government Studies, \\ North-West University, South Africa \\ ${ }^{3}$ Federation for a Sustainable Environment, Johannesburg, South Africa
}

\begin{abstract}
Gold mining in South Africa has been taking place since the late 19th Century. This activity has produced a wealth of richness for the country, but also has contributed to create environmentally destructed environments. The West Rand Municipal region is the area of focus in this paper. Possible negative environmental health outcome scenarios in especially the pollution of the area's water resources - have been speculated on in scientific reports and in occasional whistle blowing efforts. Some include official reports with regard to a radioactive contamination of the physical and man-changed environment; nonradioactive chemicals found in the residues and wastes produced by gold mining; radon gas and windblown dust. Primarily because of whistle blowing efforts, as based on scientific reports, concerns regarding human health became more intense. The paper mainly provides a concise historiography regarding the close to 100 years of environmental research by especially scientists on the West Rand region, and references to possible health risks. In conclusion ideas will be exchanged on current environmental remedial actions with a motivation for definite health related research to support environmental remedial processes.
\end{abstract}

Keywords: environmental health, environmental management, research, scientist, West Rand, environmental remediation, water pollution. 


\section{Introduction}

In the West Rand Municipal area, the existence of gold mines since especially the 1930s has played a decisive role in influencing the environment, the economy, the people and most probably their health. The biggest environmental destructor is water [1] and the way in which water has been managed [2] in the process of exploring gold. The tributary of the Mooi River drainage system is located to the west of Johannesburg in the present Gauteng Province [3]. The region is geologically notable for its complex system of dolomite compartments [4]. The terrain of the area is relatively flat with elevations ranging from $1750 \mathrm{~m}$ above mean sea level in the southeast to 1400 metres at the confluence with the Mooi River. The topography of the area is dominated by the Gatsrante, a series of east to west trending cuestas with an average height of approximately $100 \mathrm{~m}$ above the footslopes [5]. Due to extensive gold mining in most parts since the 1930s the topography of the Wonderfontein Spruit has been drastically altered in its upper reaches. The main impact has been the physical presence of mine tailing dams, rock dumps and surface infrastructure. Man-made sinkholes also formed in this catchment area as a result of the dewatering of the dolomite compartments by the gold mines since gold mining exploration started [6]. Amongst others, the Mooi River downstream was seriously contaminated [7].

The West Rand Area has been explored by many scientists from a variety of disciplines [8]. The study area is the catchment of the Wonderfonteinspruit from the continental divide near Mogale City, its source, to the confluence with the Mooi River, east of the Boskop Dam. Approximately $7 \mathrm{~km}$ downstream of the confluence the surface water and some groundwater from the Gerhard Minnebron gravitate, flow and are collected in the Boskop Dam. This 'reservoir' supplies potable water to Potchefstroom (city with close to 200000 inhabitants) located another mere $12 \mathrm{~km}$ downstream (See Figure 1 for the locality of the West Rand area). Recorded economic activity in the area can be retrieved from the 1850s [9]. Due to gold mine activity [10] several towns were founded in the area [11].

Before the cementation process was introduced in South Africa in 1916 [12], gold mining in dolomitic areas in South Africa was regarded as taboo. This economically inspired decision reached the West Rand area by the 1930s [13]. The pumping out of the surplus water gradually destroyed the local water resources. Sinkholes, related to dewatering, manifested in the Venterspost area by 1940 . The Venterspost Eye already stopped flowing during 1947. Mines were then tasked to distribute the pumped underground water through a channel pipeline to farmers. Large-scale environmental impacts on the local communities eventually necessitated an involvement of government as mediator. However, it was felt that government is selective in its actions to solve concerns. It was the agricultural sector that was the first to raise concerns regarding the effects of the water quality in the area on crops and animals. Because of the pumping of slimes into the sinkholes the impact on the environment was also felt [14].

During all these events, scientists from various institutions were commissioned on a regular basis to do research on the environment for specific 
purposes and reasons. The possible physical effects of environmental destruction on people were no serious agenda point at any stage up to the early $21^{\text {st }}$ Century. A political manifestation during this process was that in 1994, basing its policy on the premise that environmental dysfunction was rooted in apartheid and white domination, the incoming African National Congress (ANC) government responded by eventually adopting new environmentally focussed acts [15]. Theoretically impressive to look at but basically harmless at this stage in a practical application regarding environmental constraints in specifically the West Rand. This paper mainly explores the research of scientists and the utilizing of scientific reports in understanding and improving the environmental distortions of the West Rand regarding its possible effects on people's health due to century old gold mining activities.

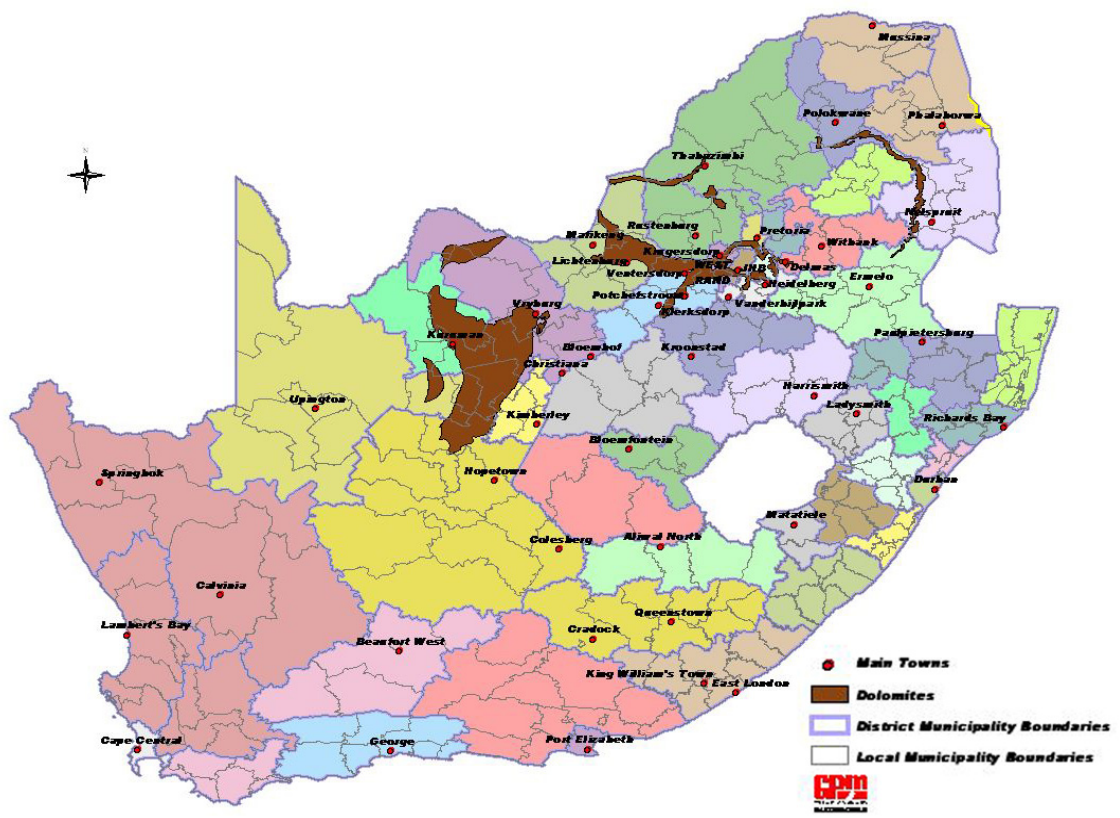

Figure 1: Topographical map of the wall-to-wall municipalities and the Karst areas in South Africa.

\section{Gold mining, environment and health: scientific indicators since the 1900s}

During the $19^{\text {th }}$ and $20^{\text {th }}$ century a vast network of scientific institutions ranging from centres of research and training to regional and national conferences were developed. In the British colonial era in South Africa it appears that some effort was made to ensure that the wide range of natural sciences interacted with the social sciences such as demography and anthropology. So a web of knowledge was produced to facilitate efficient exploitation of the natural resources. This 
approach gradually changed to reflect agendas by "many colonial scientific officials". Trends in the history of most natural sciences in for example Southern Africa have been to "subsume science within wider processes such as the political economy of imperialism. In doing so, scholars base their work on the assumption that science and scientific ideas were deeply embedded in imperial rule and not an independent lever externally brought to bear on contemporaneous political and economic events". As science then was regarded in the colonial era as one of the "tools of empire" so scientists were seen as "servants of the colonial state". Social reformer RO Polanyi's argument was that in modern societies the economy was "disembodied" from its social base because in these societies nature and human labour were exploited to satisfy economic goals under the assumption that economic growth would in turn yield societal benefit.

From a $20^{\text {th }}$ and early $21^{\text {st }}$ century perspective this colonial and imperial labelling scenario [16] in many ways even fits the present day shoe. As for the West Rand, scientific research by the natural sciences, and other observation recordings that reflect glimpses from a social science perspective, provide the present day scientist and community with valuable environmental footprints of knowledge and evidence that existed at a certain point in time. These valuable "chambers" of knowledge were not necessarily utilized to benefit the environment or to efficiently address environmental pollution matters that could possibly lead to a continuous lack of health and to fatal illnesses. The reality that possible health concerns, as a result of the century old gold mining operations in the West Rand area, currently dominate issues in the whistleblowing focus is because it is realized that mines have already closed and many more may face closure soon and that communities will be left with the environmental and physical scars. If one turns back the clock many examples of scientific research regarding the environmental knowledge of the time in the West Rand comes to mind as a kind of a rehearsal as to what was known regarding the specific area in which gold mines operated. Of the first geological surveys related to the Wonderfonteinspruit Catchment in the West Rand date from 1902 to 1939 [17].

Perhaps one of the most important analyses to be made from these surveys as viewed from a socio-historical perspective is that the Department of Mines (DM) of the national government also commissioned some research surveys on the wider West Rand environment. These research reports mainly were assignments to assist the mineral exploitation companies at the time to identify and efficiently explore the underground mineral richness, and to progress towards retrieving the country's mineral resources effectively for a long term in order to benefit developers, government and for the sake of economic progress for all [18].

In $1935 \mathrm{JE}$ Schnetler was the first to produce an unpublished dissertation on "The dolomite plain of the South-Western Transvaal". The research data Schnetler reported must have been available to the gold mines and the Government. It is interesting to note the level of the knowledge that scientists were supposed to have by 1935 on the chemical features of dolomite. On limestone's visibility in the dolomite areas of the West Rand Schnetler [19] remarked on the following: 
Secondary limestone is extensively developed in the South-Western Transvaal dolomite area. The limestone is derived from the dolomite... The limestone is formed by the slow evaporation of water containing carbonate of lime in solution...

From a $21^{\text {st }}$ century perspective and with a wider knowledge regarding limestone in dolomite it is said that limestone can be used for the treatment of acid mine water pollution which is a common feature in gold mining activities, even since the early days of mining (and also indirectly affects people's health).

After Schnetler's dissertation it took more than 35 years for new research foci to be launched and made available in unpublished form. Furthermore university academics were in a position to be exposed to local, regional and international conferences on geology [20], geography, engineering and other environmental related issues with the intention to understand and deal with local issues and constraints, and even to be able to make groundbreaking contributions. It is ironical that apparently nothing constructive to prevent environmental exploitation evolved from these actions as information applicable to the South African scenario. This was despite the fact that some publications at that point in time indicated the serious effects of mining in dolomitic areas.

That new environmental research was conducted by tertiary institutions up to the early nineties can imply that the information needs, after the dewatering and sinkhole escapades of the fifties and the decades to come, still required more analysis and understanding of a dolomitic environment such as the West Rand. In some of these studies the sponsorship of gold mines is acknowledged that may, in some way or another, signal warning lights to some present day researchers and environmentalists. Several postgraduate treatises were done on the geological features of the broader West Rand area, as well as the general development potential of the environment [21].

Apart from research on the stability of sites a possible pollution due to heavy metals received attention from upcoming academics by at least the late seventies, and was most of the time based on extensive research data from abroad. For example, JJ Malan in 1981 stated that Radium -226 is a transformation product in the uranium -238-decay series, and is present in both uranium and gold ore. As a consequence radium-226 appears in all mine tailings and it is traceable in all mine sand dumps and slimesdams of South Africa. What does Malan inform us on as far as what mines and government knew and did not know by 1981 ? Definitely they must have been aware of the maximum Radium concentration in environmental water set by the International Committee on Radiological Protection in 1967. Malan also mentioned that hazardous material like sand heaps and slimesdams close to goldmining activities necessarily impacts on an ecological system [22]. These remarks definitely were not a brainstorm resulting from 1981 research but from given facts long before Malan's observation. During 1979-1980 Malan also tested the average presence of the Radium-226 concentration of slimesdams in the Bank-Randfontein area (part of the West Rand) and found that it was substantially higher than in the Central and the East Rand (namely $1.18+-0.80 \mathrm{~Bq} / \mathrm{g}$ ). 
Some other scientists confirmed Malan's findings afterwards [23]. Years later Wymer [25] advised the affected members "that we have little choice but to accept that some of the radioactivity levels measured may indeed be cause for some concern". It was recommended that the mining industry should establish a proactive and open strategy for addressing the issue. Another year later scientist $\mathrm{H}$ Coetzee of the Council for Geo Science investigated the relative radio-isotope composition of the sediment as well as the inflorescence around the Turffontein Eye and concluded that there was an elevated level of radioactivity [24] and that the source was most likely the mines [25]. Nothing seriously happened to address these research findings. History simply continued to repeat itself with no serious learning curve and remediation efforts on the horizon.

Another scientist, AN Clay, also mentioned that numerous theories had been proposed to explain the mode of origin of dolomite, but that it was only with the discovery of recent and modern dolomite "that any progress in understanding these rocks has been made". If Clay refers to findings in for example the 1970s one might have some understanding - from a mining perspective - on why it took close to 40 years of environmental destruction to actually understand the full implications of past ignorance in the solo process of decision making. A higher than usual chemical analysis of the dolomite in the West Rand was the finding of Clay in samples from mining boreholes that were taken in 1981. And the presence of a few heavy metals was also analysed [26].

Research in the nineties marked a more proactive approach (as in the sixties by farmers) in accentuating that the gold mines are the main polluters of the local environment. After for example some investigation in 1993 it was found that the bacteriological pollution of the water issuing from the pipeline at Oberholzer was severe and recommended that this water be removed from the irrigation reticulation. Also the problems of the members of the Oberholzer Irrigation Board were investigated in September 1992. It was found that a major management problem encountered by the Irrigation Board was the accumulation of sediment in the canals. Already on 28 September 1992, at a meeting of the irrigators to discuss their problems, representatives of Gold Fields denied that the sediment came from the mines. At another meeting with the former West Driefontein Mine, the denial was repeated and the farmers were warned that the Mine had "deep pockets" and would keep them in Court for "60 years". As a result of the three decades long complaints by farmers on the impact of the water quality on the soils and animal health a study was mandated by DWAF in 1993. These results, though still unknown, were not accepted by the farmers because of the dominant mining involvement (West Driefontein Gold Mine and the Far West Rand Dolomitic Water Association (FWRDWA) [27].

To at least address this matter which was becoming serious, the Enforcement Directorate of DEAT was approached after 1998 to accentuate the responsibility of the municipalities with regard to environmental issues related to water and air pollution. Therefore local governments in the West Rand were assigned by government structures to be more responsible for the local environment [28] The City Council of Mogale City, for example, assigned some water related research of which the results were not widely distributed but in which the findings were 
not merely surprising but indeed disturbing. During the nineties a few articles by scientists also hinted at the possible effects of mining pollution on the environments in which they operate. These writings, carefully phrased in published papers, were harmless because they never reached the ears and eyes of those they directly concerned [29].

Besides the tertiary research input by academics, the seventies and eighties also gave rise to more research involvement on a consultation basis by established and new research institutions with a governmental backing. These included the Council for Scientific \& Industrial Research (CSIR) [30], the Institute for Water Quality Studies (IWQS) [44], the Water Research Commission (WRC), the Council for Geo-Science (CG), as well as private research consultants [31] that government and mining companies had commissioned from time to time. Also to do research in the West Rand on issues of concern.

A difference between research reports of an academic nature and commissioned research by companies or bodies (and consultants) are that not all in the past (and some still don't) were exposed for public eye. Some consultants have later on produced whistle blowing articles ([32] or simply kept the silence on critical issues [33] which in turn, questioned the ethical approach of scientists and professionals on environmental issues of a broader concern.

In a confidential study in 1957 by the Council for Scientific and Industrial Research (CSIR) on behalf of New Consolidated Gold Fields Limited the dewatering of the springs was confirmed [34]. Next to follow was the Final Report of the Inter-Departmental Committee on which a Dr GJ Stander, Director of the National Institute for Water Research, commented on 10 February 1964 after having difficulty in obtaining the report [35]. Apart from the fact that the Institute he was working for was not consulted, Stander also pointed out environmental destructors that needed attention in the West Rand area, namely the danger of pollution; the quality of the water that would reach the different communities; the protection of a National Asset (the Dolomitic compartments should not be used as dustbins) and need for pollution-prevention planning.

This valuable advice by Stander regarding the environment and human health was bluntly ignored by mining and government controlled research bodies like the FWRDWA and the State Co-ordinating Technical Committee (SCTC) [36]. Both these bodies operated from respectively 1963 and 1964 [37]. Continuous allegations between a dissatisfied farming community and the mines probably led to the Deputy Minister's announcement in November 1967 that concerns as raised by the farmers would be investigated. N Stutterheim of the CSIR chaired this process. At the same time the Farmers Union (FU) compiled a memorandum on the impact on animals and crops that was presented to the then Deputy Minister of Water Affairs, H Martins [38]. The above scenarios and speculative findings were not taken seriously but were suppressed. The mining authorities, by the eighties, had become the prime "managers" of the agricultural areas in the Oberholzer district, which perhaps deliberately quietened the regular complaining voice of the agricultural community [39]. 
The power to commission scientific research regarding these concerns remained in the power structures of the mines and the government. After all, to quote Turton et al [40] government i) makes the rules as their legislative obligation ii) applies the rules as their executive obligation towards the country's people and iii) adjudicates rules when required to benefit the majority of the country's people. In the process they also had the capacity to direct and enable the science field to develop solutions for the problems and needs of society. To what extent they utilized the following research information by researchers of the CSIR for the explicit attention of government so that informed decisions on environments in which gold mines operate could be made, is unknown but certainly not yet groundbreaking [41].

At the time of writing no research project, focused on research to directly complement the health impacts of mining activities on humans, has been commissioned. However, some research done by the area's gold mining companies in the past did focus on the health status of their mining work force. These findings were never released to a wider audience but simply internally utilized or dealt with. Government has commissioned a few research assignments through respectively the DM and the DWAF. The so-called Jordaan report, the Truter report (as compiled by the Joint Committee on the Dewatering of Mines in the West Rand) as well as the Gibbs Report were recorded from the late fifties to the mid-sixties [42]. Concerning the Jordaan Report of 1960 by the Department of Water Affairs on the study area, one of the adverse impacts that was foreseen was the contamination of the water by the mines, particularly sulphate contamination [43].

No specific action or environmental remediation is recalled that addressed the possible impacts of dewatering as stated in the Jordaan report. Close to a half century later, at least four research efforts comes to mind in which the direct focus was to determine the level of water pollution. Perhaps an indirect intention was to determine the possible effects pollution may have had on efforts to ensure a healthy environment for local communities. These reports are:

- DWAF, IWQS, April 1999, “The Radioactivity Monitoring Programme in the Mooi River Wonderfonteinspruit) Catchment", Report $\mathrm{N} / \mathrm{C} 200 / 00 / \mathrm{RPQ} / 2399$, Pretoria. In this report possible health risks in the area was based on researching the levels of radioactivity in raw water samples that had been filtered prior to analysis, and on the use of such water for drinking purposes on a continuous basis. The study unfortunately did not consider radioactivity in sediments, therefore the study did not shed any new light on the effects of possible water pollution on people. Also the IWQS as a valuable departure to conduct water quality studies ceased their operations shortly after this report.

- DWAF, "Radioactivity Study on Sediments in a Dam in the Wonderfonteinspruit Catchment", Report, 2002, Pretoria.

- WRC, F Winde, "Impacts of gold-mining activities on water availability and quality in the Wonderfonteinspruit catchment", in H Coetzee (ed.) An Assessment of Current and Future Water-pollution Risk with Application to 
the Mooirivierloop (Wonderfonteinspruit). Report K5/1214, Pretoria, 2005, pp. 14-38.

- $\quad$ CG, H Coetzee; J Venter \& G Ntsume, "Contamination of Wetlands by Witwatersrand Gold Mines - Processes and the Economic Potential of Gold in Wetlands" Report 2005-0106, 2005, Pretoria.

Scientist F Winde of the North-West University confirmed that an investigation aimed at establishing possible health implications in affected communities in the West Rand is still due. An effort to assess associated health risks is further complicated by a number of facts including the lack of reliable data on effects of long-term low-dose exposure of humans to uranium in drinking water and limited understanding of the complex mechanisms and dynamics of uranium pollution and uranium transport in the aquatic environment. To the ordinary citizen it is not currently known how many unpublished or restricted reports have been produced that relate to the environmental pollution problems in the West Rand which may impact (or/and already have impacted) on the health status of the communities living in these areas. Most mining commissioned research reports are not available and/or easily obtainable [44]. The scenario of not having access to valuable report data is just as common as the secrecy of research reports. Water expert, A Turton, speaks as if nothing has changed:

I have just got the 1958 Sodium Chloride report. It is amazing. But it is classified so it cannot be released. We can discuss this because I believe it should be released. Permission would need to come from Gold Fields, the new owners. The Jordaan Report builds on the CSIR NaCl report and also a Floculation Report so they are a family. Anthony Turton, 6 Jul 2007 (E-mail to multiple recipients)

\begin{abstract}
AND
This classification business is a hangover from the past, and in my view is probably manageable through negotiation. The right to release is vested with the "owners" of the report and that is GFSA by virtue of their acquisition of the mines in question.

Anthony Turton, 16 Jul 2007 (E-mail to multiple recipients)
\end{abstract}

Some of the most recent publications worth mentioning that refer to environmental related research with health pointer foci as done by professionals and scientists are:

- H Coetzee, "Radioactivity and the Leakage of Radioactive Waste Associated with Witwatersrand Gold and Uranium Mining”, in B Merkel, S Hurst, EP Lohnert \& W Struckmeier (eds.), Proceedings of the International Geo Congress Conference and Workshop, Freiberg Germany, October 1995, pp. 34-39;

- $\quad \mathrm{H}$ Coetzee, P Wade \& F Winde, in BJ Merkel, B Planer-Friederich \& C Wolkersdorfer (eds.). "Reliance on Existing Wetlands for Pollution Control 
Around the Witwatersrand Gold/Uranium Mines in South Africa - Are they Sufficient?", Uranium in the Aquatic Environment, Berlin: Springer, 2002, pp. 59-65;

- $\quad \mathrm{K}$ Takai, DP Moser, TC Onstott et al., “Alkaliphilus transvaalensis gen. Nov., sp. Nov., an extremely alkaliphilic bacterium isolated from a deep South African gold mine", International Journal of Systematic and Evolutionary Microbiology, 51(t 4), Jul. 2001, pp. 1245-1256;

- DP Moser, TC Onstott, JK Fredrickson et al., "Temporal shifts in the Geochemistry and Microbial Community Structure of an Ultra Deep Mine Borehole Following Isolation”, Geomicrobiology Journal, 20, 2003, pp. 517-548;

- F Winde \& IJ van der Walt, The significance of groundwater-stream interactions and fluctuating stream chemistry on waterborne uranium contamination of streams - A case study from a gold mining site in South Africa, Journal of Hydrology, 287, 2004, pp. 178-196.

- $\quad$ RA Adler; M Claassen; L Godfrey \& AR Turton (2007), Water, mining and waste: An Historical and Economic Perspective on Conflict Management in South Africa, The Economics of Peace and Security Journal. 2(2), pp. 33-41.

- $\quad$ AR Turton, "South African Water and Mining Policy: A Study of Strategies for Transition", in D Huitema \& S Meijerink (Eds.), Water Transitions. Netherlands: Edgar Elger, 2009.

Recent research which was more explicit regarding the detrimental environmental and health related effects due to gold mining activities and treated with secrecy for some time before making it public, are:

- National Nuclear Regulator (NNR), 2007. Radiological Impacts of the Mining Activities to the Public in the Wonderfonteinspruit Catchment Area. Report No. TR-RRD-07-0006. (Also known as the Brenk Report). Pretoria.

- $\quad$ NNR, R Barthel, G Deissman \& W Leotwane (2007), "Radiological impact assessment of mining activities in the Wonderfonteinspruit Catchment area", Paper that was avoided to be presented at the Environment Conference, Pilanesberg, NWU, South Africa, 23-25 July, 2007 [45]. In this report the radiological risks of the mining activities for cattle being watered at polluted surface water bodies in the Wonderftontein Catchment area in the West Rand were extensively looked into.

All the research as indicated above not only accentuates a high research involvement of scientists in the study area, but also sadly reflects how little impact their findings had in their time regarding for example water pollution. More whistleblowing concerns are found regarding the area as recorded from 2003 to 2009 in which scientific report findings and suggestions also feature as a kind of confirmation that government and goldmines should react in a progressive way to remediate the environment for the benefit of affected communities (also health wise) and for the sake of future generations. Some of these whistleblowing concerns were initially rallied and continuously driven by one of the Directors of the Federation for a Sustainable Environment: Me Mariette Liefferink. On these whistleblowing campaigns the newspaper Beeld 
has fed ordinary citizens with information on the status of the study area on a regular basis [46].

Other media organs and newspapers followed suit, with some reasonable success regarding the creation of awareness, and eventually the development of a more proactive approach towards environmental remediation for the sake of a sustainable environment regarding the future of local communities. Several local bodies and committees were founded during the early $21^{\text {st }}$ century to accommodate all stakeholders in the West Rand and the West Rand environment. Some still function whereas others have ceased their operations due to complexities and differences regarding how the future should look [47].

However, a research request that has remained in the background, as if not even speculated on or mentioned at any point in time, is the call for studies to determine the impact of gold mine pollution on the health status of local communities. Though some scientists recently have suggested that some steps in this direction should be considered, no substantial funds were available at the time of writing, or have been commissioned by for example the government and the mines [48].

Anthony Turton (former Director of the Water Research Division at the CSIR) recently remarked that South Africa currently faces a serious water quality challenge, both in the eyes of the public and by scientists. He also accentuated that the impact of mine water quality on humans is largely unknown and has not yet been studied in South Africa. A proposal that was submitted by the CSIR in 2008 to the WRC to address this deficiency was unfortunately rejected, "so the state of knowledge around this crucial area is still very weak" [49].

\section{Possible solutions to improve environmental management in the region}

If the past should act as a springboard for what should be done and what should be avoided in an environment like the West Rand, the following immediately comes to mind: Do thorough research that will be widely available to all interested [50]; Act proactively in response to voices of concern regarding the degrading of the environment and sufficiently address rumours regarding health problems with focused research projects; Remediate more proactively. This is only possible if those mainly responsible for causing pollution can be forced by law to implement operational plans in this regard. Environmental destructions could then be constructively avoided; To define and explore best practices for reducing the health and environmental impact on soil and groundwater from industrial sectors of interest (e.g. mining). Undoubtedly all role-players will be engaged in order to explore the techniques and technologies for preventing and avoiding discharges to soil and groundwater as well as remediation programmes for the mining sector [51].

Currently individual gold mining companies are co-operating with academic institutions to address a variety of environmental impacts and to exploit the potential of wetlands to act as a sink for heavy metals [52]. However, on the 
negative side of efforts, mining closures became a reality in which the quality of surface and groundwater can further deteriorate [53]. Also the underestimated role of environmental whistleblowing sometimes is branded by critics as "looney tune stuff." It will take wisdom, resources, ideas and knowledge to make a meaningful difference [52].

A factor influencing clarity, knowledge and responsibility is the regular lack in communicating relevant scientific evidence or/and findings. Therefore the debates on all forums and committees tend to remain denial like, selective, distorted and artificial [54]. As part of their efforts towards finding all-inclusive solutions for environmental pollution issues DWAF has recently established the Western Basin Void Decant Technical Working and Monitoring Committee, The Wonderfontein/Loopspruit Forum and the West Rand District Waste Management Forum. It is sometimes poorly attended by representatives of government, communities, civil society groups and non-government organisations (NGOs). A representation from poor, predominately black communities is not good [55] due to several complicated reasons.

There is a need for more opinions and input in finding solutions. In the past, efforts towards sufficient pro-activity and environmental remediation were hindered by individuals and the mines, as well as the government (local and national), due to scientific selfishness, differences and economic greed [56].

Only recently a report was released by DWAF to announce a three-year environmental remediation plan for the Wonderfonteinspruit Catchment in the West Rand area [57]. If implemented efficiently this process may also impact positively on the health status of people in the long term. However, this sign of progress does not imply that the need for research in the environmental impacts on people's health should be nullified. Recent research has pioneered concerns in this regard and the scientific community should follow up to search for information that will enhance a better understanding of the impacts of man on man in an environment of this nature.

\section{Conclusion}

In the discussion it has been accentuated to what extent different economic ideals and insufficient communication among stakeholders as well as an insufficient application of research data can have an impact on the environment and can lead to enormous environmental management complexities over time. After close to 80 years of active gold mining operations in the area, in which minor efforts of remediation to the advantage of the environment and communities were made, it has become an extraordinary challenge for younger generations to propose constructive solutions. Equally the effective application of scientific research and results to, for example, address possible health risks in the West Rand gold mining region of South Africa, simply do not happen because of a fear of the expenses that may result if mines are pointed out (with actual evidence), as the party that affected people's health. Furthermore differences of opinion or an inclination to exclude role-players also prevail and complicate this historically driven scenario even further. From a national point of view the question of 
environmental ethics and to what extent human rights can be demanded regarding individuals and communities whose health status may have been affected will become significant issues in research themes based on the impact of the destructed environment in the study area on the health of people. On the question then regarding what role science could play in the democratic South Africa Turton [52] has commented:

If the national science councils are forced to continue as commercialized entities, then they run the very real risk of being hijacked by private interests intent on maintaining the status quo in the country. This will lock in existing inequities and could potentially undermine the stability of our fledgling democracy. On the other hand, if our national science councils are given robust grants and a focused research agenda that meets the national interests as broadly defined, then science could play a vital role in addressing past inequities and helping with the transition to a more stable society in which the core values of democracy are deeply entrenched.

If the environmental destructions in the West Rand continues in future without a sustainable plan to properly manage the variety of concerns raised, this area will not sufficiently recover to at least supply those living in it with a reasonable chance of survival. With the mines in a process of moving out as the dominant economic sector, the area indeed may be irreversibly destroyed for the people, for farming, as well as for cultural and environmental sustainability. The role that capitalism, racism and nationalism would have played then can become interesting debates but will never bring back what once was. However, most importantly at this stage is to progress in the scientific research focus by moving on in time and conducting health impact assessments especially regarding mining pollution matters. The past has pointed out several ground breaking research reports that were requested and suitable for a specific timeframe, though these were not always applied to benefit a wider population. Perhaps constructive global discussions on many similar examples worldwide should also be explored and possible solutions posed that can apply to this unique micro community scenario.

\section{References}

[1] AS Hollander's recent publication entitled The water business. Corporations versus people (The University Press, Bangladesh, 2005), pp. 64-80, 195-212, 239-261.

[2] AG Oosthuizen, "Die rol van water in die ekonomiese ontwikkeling van Streek A, 1980-2010 (MA., PUvCHO, 1987); JP van Brakel, "Water as beperkende faktor in die ontwikkeling van Noordwes-Transvaal. ' $n$ Grafiese evaluering", (Ph.D., PUvCHO, 1981), pp.75-75.

[3] PUvCHO, Carletonville Project, Interview EJ Stoch, 19 Apr. 1989; Union of South Africa, Dept. of Water Affairs, Report on certain Irrigation Board findings on the distribution system, 1958-1959. 1958. W.P. Series 1958(9)/1958, Pretoria,Government Printer, p. 96. 
[4] LE Kent (comp.) and SACS, "Stratigraphy of South Africa “...8, 1980, fig. 1.3.1; RA Pelletier, "Contributions to the Geology of the West Rand", Transactions of the Geological Society of South Africa, XL, July 1937, pp. 130, 139; WM Walker, “The West Wits Line”, South African Journal for Economics, 18(1), March 1950, pp. 16-17.

[5] LE Kent (comp.) and SACS, "Stratigraphy of South Africa “...8, 1980, fig. 1.3.1; JF Wolmarans, "Die ontwatering van die dolomietgebied aan die Verre Wes-Rand: Gebeure in perspektief”, (Ph.D. UP, 1984).

[6] JF Wolmarans, Die ontwatering van die dolomietgebied aan die Verre WesRand...", p. 104; WM Walker, "The West Wits Line", South African Journal for Economics, 18(1), March 1950, pp. 16-20; R Macnab, Gold, their touchstone: Gold Fields South Africa, 1887, a centenary story, (Jonathan Ball, Johannesburg, 1987), pp. 144-145; 214-222.

[7] ES van Eeden, F Winde \& EJ Stoch, "Multi-perspectives and perceptions on water quality, and related health issues, as impacted on by the mining activities in the Carletonville catchment (Gauteng Province, South Africa), 1964-2004" (Paper presented at the 5th International Congress of the Water History Association Paris, France, 1-3 Dec. 2005).

[8] ES van Eeden, AB de Villiers, AH Strydom, \& EJ Stoch, "Mines, people and sinkholes - an analysis of the Carletonville Municipal Area in South Africa as case study regarding politics of secrecy" Historia 47(1), May 2003; ES van Eeden, "Nederlandse emigrante op Wonderfontein 19281969 - 'n suksesvolle mislukking onder die vaandel van stamverwantskapsen ekonomiese motiewe", Historia, 46(1), May 2001.

[9] ES van Eeden, "Die geskiedenis van die Gatsrand vanaf die vestiging van die Trekkergemeenskap omstreeks 1839 tot die proklamering van Carletonville in 1948" (MA., PUvCHO, 1988). R Macnab, Gold their touchstone: Gold Fields of South Africa, 1887-1987, a centenary story...1987, pp. 64-161.

[10] Unie van Suid-Afrika, Departement van Handel en Nywerheid, jaarverslag no. 3, Raad vir die Ontwikkeling van Natuurlike Hulpbronne, 1 Januarie-31 Desember 1950, Pretoria, 1950, pp. 34-35.

[11] Interim Archive [IA], Carletonville Municipality [MCV], file 22/1(b)(2), Dorpe: memorandum i.v.m. die verskynsel van sinkgate en grondbeweging in dolomitiese gebiede en die uitwerking wat dit vir die toekomstige ontwikkeling van Carletonville inhou, 17.4.1976, p. 6.

[12] It was the Frenchman M Albert Francois that came from abroad to apply his knowledge and experience in the technique to the "water fault" encountered at the ERPM. See JS Crawhall, "Control of underground water by cementation", Optima, 3(1), 1953, p. 19.

[13] Compare RA Pelletier, "Contributions to the geology of the West Rand", Transactions of the Geological Society of South Africa, XL", July 1937; WM Walker, "The West Wits Line", South African Journal for Economics, 18(1), March 1950; WP de Kock, "The geology and economic significance of the West Wits Line", The Geological Society of South Africa, I, 1964, 
p. 375; R Macnab, Gold their touchstone: Gold Fields South Africa, 18871987 , a centenary story...1987.

[14] ES van Eeden, "Ekonomiese ontwikkeling en die invloed daarvan op Carletonville, 1948-1988: 'n Historiese studie”, (Ph.D., PUvCHO, 1992); Interview, Me. M Liefferink, 21 Oct 2006; National Archive(NA), Pretoria, Uitvoerend Raad van die Unie(URU), Box 3356, File 420, Onttrekking van water deur die Blyvooruitzicht Gold Mining Company, 1955; Box 3486, File 82, Abstraction of water by the Blyvooruitzicht Gold Mining Company, 1956.

[15] United Nations Development Programme, South Africa Human Development Report 2003 (Oxford, Oxford University Press, 2003), pp.128-129 as quoted in Prof J Carruthers "Transnational and transdisciplinary aspects of the environmental history of Africa" (Paper presented at the International Conference on Humankind at the Intersection of Nature and Culture, Kruger National Park, 4-6 September 2006).

[16] R Rajan, "The colonial eco-drama: Resonant themes in the environmental history of southern Africa and South Asia", in S Dovers, R Edgecombe and B Guest, South Africa's environmental history. Cases \& comparisons, (USA, David Philip, 2003), pp. 264-265, 304-305.

[17] See for example HB Bunkell, "Geology of the Krugersdorp District", Trans. Geological Society of South Africa, V(iv), Johannesburg, 1902; DMI, Annual Report, 1907; DMI, Geological Survey [no number], 1921, ET Mellor, "The Geology: Country surrounding Johannesburg" (Government Printer, Pretoria, 1921), pp. 45,47; DM, Geological Survey 6869, 1935, LT Nel, HF Frommurze, J Willemse \& SH Haughton, "The geology of Ventersdorp and adjoining country", (Government Printer, Pretoria, 1935); DM, Geological Survey 4423, 1939, LT Nel, FC Truter \& J Willemse, "The geology of the country around Potchefstroom and Klerksdorp (Government Printer, Pretoria, 1939).

[18] See DM, Geological Survey, LT Nel, HF Frommurze, J Willemse \& SH Haughton, "The geology of Ventersdorp and adjoining country"...1935, pp. $43,66-70,73$ as a typical example.

[19] JE Schnetler, "The dolomite plain of the South-Western Transvaal", (MA dissertation, University of the Witwatersrand, 1935), pp. 17; 51$52 ; 72 ; 105$.

[20] JE Jennings, ABA Brink, A Louw \& GD Gowan, "Sinkholes and subsidences in the Transvaal Dolomites of South Africa", (6th International Conference, Soil Mechanics and Foundation Engineering, Montreal, Canada, 1965).

[21] See for example B Krapez, “A sedimental study of the Ventersdorp contact reef at East Driefontein Gold Mine, Carletonville, South Africa" (MA., University of the Witwatersrand, 1979); AN Clay, "The Geology of the Malmani Dolomite subgroup in the Carletonville area, Transvaal" (MA., University of the Witwatersrand, 1981); JJ Malan, "Die bepaling van radium-226 in die uitskot van goudmyne en hulle omgewings" (MA., UP, 1981) (this is a study on radion impacts from gold mining on the immediate 
environment); CB Schoeman, "Die beplanningsimplikasies van die proses van funksieverandering by myndorpe met spesiale verwysing na die Witwatersrand (D.Phil.. PUvCHO,1986); (This is a study on town planning and management research regarding mining towns that include parts of the West Rand); DB Butrick, Characterisation and appropriate development on sites of dolomite (DPhil, UP, 1992). p. 80.

[22] JJ Malan, "Die bepaling van radium-226 in die uitskot van goudmyne en hulle omgewings" (MA-verhandeling, UP, 1981), p. 1; International Commission on Radiological Protection (ICRP), "Report of Committee II on permissible dose for internal radiation" (Pergannon Press Ltd., London, 1967), p. 77 as quoted in JJ Malan, "Die bepaling van radium..." ...; JE Johnson, "Pathways of Radionuclides released from tailings piles", Symposium on Uranium Mill Tailings Management, Fort Collins, Colorado, November 1978 as quoted in JJ Malan, "Die bepaling van radium-226...".

[23] Obtained from Prof EJ Stoch, Memorandum, Krugersdorp Game Reserve: Animal mortality. V2, 13 May 2005, pp. 5-6.

[24] Henk Coetzee was also part of the controversial 2006 WRC report $1214 / 0 / 06$.

[25] H Coetzee, personal communication Prof EJ Stoch (Agronomist), Personal collection; Wymer (1995) as quoted by EJ Stoch,Memoires, 1 Aug. 2006.

[26] AN Clay, "The Geology of the Malmani Dolomite subgroup in the Carletonville area, Transvaal" (MA dissertation, University of the Witwatersrand, 1981), pp. 47-48; 60, 62-67.

[27] EJ Stoch, Personal collection, 1 Aug 2006.

[28] H Thompson, Water law: A practical approach to resource management \& the provision of services (Cape Town, Juta \& Co, Ltd, 2006), pp.235-236; RF Fuggle \& MA Rabie, Environmental management in South Africa (Cape Town: Juta \& Co, Ltd, 2005), pp. 293; 315; 459; 490.

[29] $\mathrm{S} \mathrm{du}$ Toit, Draft report water contamination in the Krugersdorp area at the request of Mogale City, 2007.

[30] ES van Eeden, AB de Villiers, AH Strydom \& EJ Stoch, "Mines, people and sinkholes...", Historia 47(1), May 2003.

[31] DG Kingwill, The CSIR: The first 40 Years. Pretoria, CSIR Information Services, 1990.

[32] IWQS, "The Radioactivity Monitoring Programme in the Mooi River (Wonderfonteinspruit) Catchment”, Report N/C22/00/RPQ/2399, Pretoria, 1999.

[33] CG Mitchell \& NW Quinn, "Environmental reporting disclosure in South Africa: A comparative study of the expectations of selected groups of preparers and users", Meditari Accountancy Research, 13(2), 2005, p.19.

[34] N Funke, K Nortje, K Findlater, M Burns, A Turton, A Weaver \& H Hattingh, "Redressing inequality: South Africa's new water policy", Environment, 4, January 2007.

[35] ES van Eeden, "An historical assessment of NGO efficiency in progressing towards a sustainable environment heritage focus, with as case study the 
Wonderfonteinspruit catchment, Gauteng", New Contree, 53, 2007, pp. 5580.

[36] EJ Stoch, Personal collection.

[37] CG, Archival material on the SCTC and the FWRDWA.

[38] EJ Stoch, Personal collection: Circular, 28/67, Letter, Chairman, FWRDWA, 1967.

[39] EJ Stoch, Personal collection: Draft notes for paper on "Some controversial health related issues in a karst environment"/ES van Eeden, ca 2005.

[40] A Turton, HJ Hattingh, GA Maree, DJ Roux, M Claassen \& WF Strydom, Governance as a trialogue: Government-Society-Science in transition, (Berlin, Springer, 2007), pp. 13-14.

[41] See for example: CSIR, B Genthe \& M Steyn, "Parliamentary briefing paper on endocrine disrupting chemicals", Report CSIR/NRE/WR/IR/ 2008/0079/C, 2008; Also in the same report: P Hobbs, "Parliamentary briefing paper, Acid Mine Drainage"; P Oberholster, "Parliamentary Briefing Paper on Cyanobacteria in Water Resources of South Africa, 2008.

[42] A Turton, HJ Hattingh, GA Maree, DJ Roux, M Claassen \& WF Strydom, Governance as a trialogue: ...".

[43] ES van Eeden; F Winde \& EJ Stoch, "Multi-perspectives and perceptions on water quality...." (Paper presented at the 5th International Congress of the Water History Association Paris, France, 1-3 Dec. 2005).

[44] As examples the following are recalled: Chamber of Mines of South Africa, MJ Mrost, "Report on an investigation into mine effluents", 1957; A Louw, "Memorandum on a sinkhole on slimesdam No. 2 of West Driefontein GM", Unpublished, 1962; Deelkraal Gold Mine, "Pilot study to determine uranium levels in urine of underground mine workers at Deelkraal Gold Mine", ca post 1990; Chamber of Mines of South Africa: W Pulles, "Radionuclides in South African gold mining water circuits: An assessment of licensing, health hazards, water and waste regulations and impact on the environment and workforce", Unpublished restricted report, no 17/91, Programme reference GE1C, April 1991; Driefontein Consolidated Gold Mine, J Slabbert, "Radioactivity concentrations in water leaving West Driefontein GM", Unpublished, 1996.

[45] EJ Stoch, personal collection: Minutes Interdepartmental Committee, minute, 6th Dec. 1956, pp.1-6. The full title of the Jordaan Commission Report is: Finale Verslag van die Tussendepartmentele Komitee insake Dolomitiese Mynwater: Verre Wes-Rand Gerig aan sy Edele die Minister van Waterwese deur die Direkteur van Waterwese - Mnr. JM Jordaan, Direkteur van Waterwese, 1960.

[46] As examples see E Tempelhoff, "Gifspruit" (Poison Stream). Beeld Newspaper. 3 Feb. 2007; "Gifstof in Kos Skok: Radioaktiewe Stowwe in Voedselketting" (Toxins in Food Shock: Radioactive Substances in Food Chain). Beeld, 1 Feb., 2008.

[47] See for example F Winde, "Interactions between groundwater and surface water in dolomitic areas affected by Deep-level gold mining - examples 
from the West Rand goldfield (South Africa), CSIR", Abstracts of the Biennial Ground Water Conference 2005, 7-9 March, 2005, pp.1-2.

[48] G Offringa, N Mjoli, SN Venter, R Kfir \& A Moolman, “A New Strategic Framework for Water-Related Health Research", in Water SA. (33)5, 2007; S Smillie, "Tooth Fairy Project May Reveal Effect of Uranium", The Star, $18 / 3 / 2008$.

[49] A copy of the Report is available in the personal collection of EJ Stoch. The uranium results at the Deelkraal Gold Mine was said to be abnormally high.

[50] Personal Collection, M Liefferink: E-Mail, D Fig/M Liefferink, Oct. 2007.

[51] ES van Eeden \& I Brink, "Factors that determine the facilitation of stakeholders in environmental management - some philosophical-historical thoughts with Merafong area as example", Koers, 74(4), 2007, pp. 691-721.

[52] A Turton, "The role of science in deepening democracy - The case for water in Post-Apartheid South Africa", The Journal for Transdisciplinary Research in Southern Africa, 5(1), July 2009.

[53] Correspondence, E-Mail, M Liefferink/V Munnik, October 06, 2007.

[54] Goldfields of South Africa, Notes supplied responding to questions posed by ES van Eeden by Mr Jacobs, August 2007.

[55] Compare F Winde, Interactions between groundwater and surface water in dolomitic areas affected by Deep-level gold mining - examples from the West Rand goldfield (South Africa), CSIR, "Abstracts of the Biennial Ground Water Conference 2005, 7-9 March, 2005, pp.1-2.

[56] M Liefferink, Personal collection: E-Mail, M Liefferink/V Munnik, Oct 07.

[57] ES van Eeden \& I Brink, "Factors that determine the facilitation of stakeholders in environmental management - some philosophical-historical thoughts with Merafong area as example", Koers, 74(4), 2007, pp. 691-721. 